\title{
Competition and Mission Drift in Microfinance: Does Competition has a Mission Drift Impact?
}

Hailu Abebe Wondirad*

Department of Business and Economics, Bahir Dar University, Ethiopia

\begin{abstract}
This paper analyses both empirical and theoretical evidences on competition and mission drift. The main objective of the paper is to pin-down whether competition leads to mission drift. A Comprehensive empirical examination on competition and mission drift has been conducted. To understand the theoretical foundation of the relationship between competition and MFIs' mission, a theoretical model has also seated. The paper suggests that competition helps MFIs to keep their mission of serving the marginalized poor people in such a way that competition pushes MFIs towards the unmet market demand. The analysis also finds that the results are mixed, and it is difficult and ambiguous to disentangle the phenomena of mission drift which has occurred due to competition.
\end{abstract}

Keywords: Mission drift; Microfinance; Theoretical foundation

\section{Introduction}

Microfinance is the provision of banking services to the poor people who have long been overlooked from the formal financial system due to sociological and economic reasons [1]. Microfinance Institutions (henceforth MFIs) are also institutions established to provide financial services to the poor and low income people [2]. The history of microfinance as an entity of providing financial service to poor households goes back to 1970s [3]. Since then, with varieties of organizational structures, business models and target customers, microfinance has been growing from a small microbank focused on credit only to big financial institution that provides wide ranges of services such as different form of loans, savings, insurances and remittance [4]. For last two decades, microfinance industry has been experiencing high growth [5], with a total asset of 7 billion in 2008 [6].

Recently, microfinance industry manifested by increasing commercialization [7], and has been generating significant profit [8]. The undergoing commercialization and handsome profit spurring new MFIs to enter into the market and compete for market share [9]. This new development trend of microfinance industry towards a commercial approach creates intense competition and market concentration [10]. As a consequence, nowadays, competition and commercialization are undergoing concurrently, and have a direct relationship, "one spurring the other" [10].

From the inception, by providing financial services to the marginalized poor people and disciplining efficient allocation of resources in the market, microfinance considered having models that fill market failure theory [11]. However, due to high transaction cost of serving poor people [12,13], it has been observed that, by only targeting the poor segment of market, MFIs couldn't cover their operational expenses without subsidy or supports from donors. In fact, in a competitive market, in order to provide financial services permanently, MFIs have to cover their operational expenses. MFIs have been responding to the market pressure (competition) through following different easing efficiency has been a dominance strategy. The need to implement these and others possible strategies (increasing average loan sizes, individual lending, focusing on urban clients and etc), which help to cope with intense competition, may spurring MFIs to start serving wealthier clients. MFIs were created to serve the poorest people with a mission of poverty reduction, and self- help doctrine [14]. Therefore, shifting from their original mission of serving the lower or marginalized segment of the population would consider as mission drift $[15,16]$.

From the above empirical evidences, it can be thought out that, increased in competition threatens MFIs and pushing them to strive for achieving financial efficiency that possibly weaken their social mission, and then leads to mission drift. In microfinance literatures, there are ongoing debates to answer whether microfinance is experiencing a mission drift phenomena or operating as per the defined mission. Among these empirical evidences some of them didn't confirm a mission drift $[17,10,18,19,2]$ whereas others claim that mission drift has been happening in microfinance industry [20-23]. Nevertheless, until now, there is no clear empirical evidence that shows the influence of competition on MFIs' social mission. The rapid evolution of intense competition that has been observed in microfinance raises question: does competition affects MFIs' social mission? To put differently, does competition has a mission drift effect?

Therefore, the purpose of this paper is to analyses both empirical and theoretical evidences on competition and mission drift in microfinance in order to pin down the impact of competition on MFIs' social mission. The objectives of this paper is first to examine whether competition has a mission drift impact, and second, to provide empirical evidences that explain conditions for when competition has or has not a mission drift effect.

The remainder of this paper organized as follows: Section 4 presents conceptual framework that follows. In section 5, empirical evidences on competition in microfinance industry are discussed.

Mission drift indicators are also highlighted in section 6 . Theoretical models and empirical evidences on the relationship

*Corresponding author: Hailu Abebe Wondirad, Department of Business and Economics, Bahir Dar University, Bahir Dar, Ethiopia, Tel: +251931635712; E-mail: hailat.abebe@gmail.com

Received February 23, 2018; Accepted March 14, 2018; Published March 24 2018

Citation: Wondirad HA (2018) Competition and Mission Drift in Microfinance: Does Competition has a Mission Drift Impact? J Bus Fin Aff 7: 324. doi: 10.4172/2167 0234.1000324

Copyright: () 2018 Wondirad HA. This is an open-access article distributed under the terms of the Creative Commons Attribution License, which permits unrestricted use, distribution, and reproduction in any medium, provided the original author and source are credited. 
between competition and mission drift are briefly discussed in section 7 and 8 respectively. Finally section 9 , conclusions are presented.

\section{Conceptual Framework}

To answer whether competition has a mission drift impact on MFIs, it is important to understand microfinance's framework or approach that discipline its mission, and the context of mission drift.

When framework concerns, there is an exigent debate on the approach that views microfinance, and microfinance would follows and focuses. This debate is commonly classified as "institutionist" and "welfarist" [15]. Institutionist advocates that financial self-sufficiency is a prime focus of microfinance. It implies that MFIs have to design a business model that allows them to increase access to financial services to the poor and at the same time to be financially self-sustainable without subsidy. On the contrary, welfarist claims that poverty reduction is a main goal of microfinance, poverty approach [15]. From the welfarist point of view, MFIs are developmental tool established to improve the living standard of poor people. Having such two different ideologies in the way to pursue their objectives, MFIs are vulnerable to mission drift [24]. Nevertheless, following both approaches at the same time is visible [15]. According to the authors, MFIs can undertake a business model that allows maximizing outreach (breadth and depth) and being financially self-sufficient. Furthermore, again to reconcile these two opposing ideologies and risk of mission drift, Schreiner [24] designed a framework which has six constructs (cost, worth, breadth, depth, length, and scope) that help to compromise the interest of stakeholders. Thus, in this paper, in order to pin down the influence of competition on MFIs' mission, as suggested by Woller et al. [15], the combination of both approaches (financially self-sufficiency and poverty reduction (or/and serving the poorest of the poor) are follow. To put differently, an approach views MFIs as entities that have double bottom line objectives, guides this paper.

There are also ongoing debates on the trend of mission drift and its interpretation in microfinance. Nevertheless, by reviewing previous studies, this paper tries to operationalize the context of mission drift and forwards direction. Mission drift is an occurrence that happens when "...microbanks moved away from serving their poorer clients in pursuit of commercial viability" [25]. Consistent with Cull and Morduch [25] definition, according to Ghosh and Van Tassel [26], mission drift is a phenomena occurred when an MFI shift from its' main objective of reducing poverty to profit oriented business. Armend'ariz and Labie [27] define mission drift as "...a phenomenon whereby an MFI increases its average loan size by reaching out wealthier clients neither for progressive lending nor for cross-subsidization reasons" [27]. The authors also argue that mission drift arises when MFIs' effort of minimizing average loan size is not in line with their original mission of being exist as an entity. This paper subscribes to the definition forwarded by Armend'ariz and Labie and Cull and Morduch [25,27]. Therefore, mission drift is a phenomenon occurs when an MFI creeping from serving its poor clients to the better-off clients neither for crosssubsidization nor for progressive lending rather for higher profit.

\section{Competition in Microfinance}

As stipulated above, the entrance of profit driven institutions into the market and intent of commercialization are the driver factors of competition [9]. Theoretically, competition considered as a market force that brings lots of benefits for customers [28]. Optimum efficiency, high quality of service, good product design and innovation are among the benefits of competition. From economics theoretical point of stands, in microfinance, Christen [10], and Rhyne and Otero [29] confirm that competition fosters quality of services, improves product and services design, increases efficiency and lowers price of contracts or policies.

Nowadays, there are studies that have been conducting to find the relationship between competition and microfinance operations $[9,10,21,22,29,30]$. Those researchers are documented both positive and negative aspects of competition.

According to Assefa et al. [9], increased in competition in the microfinance market creates conservative leading operations. As a result, MFIs are forced to focus on the better of clients who would show good repayment, hence lowers outreach. Additionally, their paper addresses that competition exacerbates the repayment performance of borrowers, which increased the amount of MFIs' loan at risk and wright-offs. Moreover, Assefa et al. [9] confirmed McIntosh and Wydick [22] findings' by arguing that when more MFIs entering into the market, the supply of loan in the market increases. Absences of information sharing across MFIs, and availability of more supply of loans in the market motivates borrowers to take a loan from multiple sources which in turn creates heavy loan burden and leads to low repayment performances. Altogether, according to Assefa et al. [9], intense competition has a negative impact on MFIs' financial performance and sustainability.

McIntosh and Wydick [22] suggest that competition threatens MFIs' borrower screening mechanism whereby the chance of accepting strategic default borrowers would be high. Weak clients' screening lowers repayment rate which in turn reduces MFIs' financial performance. Consistent with these findings, as Vogelgesang [30] argues, competition has both positive and negative effect on repayment behaviours of clients. On one hand, high competition increased supply of loan in the market that initiates multiple loans taking which leads to high indebtedness and low repayment rate. On the other hand, however, in areas where competition is very high, due to clients' awareness about the punishment of competitive market or negative incentive, clients have good repayment rate.

Moreover, when MFIs face intense competition in the market, they tend to increase the loan size, has a negative impact on depth of outreach [17]. On the contrary, in the later paper, Rhyne and Otero [29] argue that the presence of intense competition in the microfinance market helps MFIs to be efficient through reducing cost, enhancing productivity and designing new products and services, which ultimately foster borrowers' bargaining power.

\section{Measuring Mission Drift in Microfinance}

In recent decades, MFIs Mission drift has been proxied in different ways by different researchers. The most widely seen trend is using social performance indictors as proxy to gage mission drift. Among these, average loan size is popular tool widely used to measure MFIs' extent of targeting poor people [2,31]. Average loan seize measures depth outreach in such a way that drift appear when MFIs are striving to increase their average loan sizes [24,25]. As per Cull and Morduch [25], although, they didn't confirm mission drift, offering higher loan size is certainly a mission drift. Ghosh and Van Tassel posit this by arguing that the creep from small loan sizes to higher loan sizes are not mission drift, rather in line with poverty reduction mission [26].

Additionally, Ghosh and Van Tassel show that for successful MFIs, the increase in average loan size indicates a decrease in poverty return 
[26]. In general, when MFIs shift from their target segment (poor people) are showing a mission drift phenomenon $[15,16]$.

But, in different time researchers suggested that exclusively judging the position of MFIs' mission drift tendency using the shift in average loan size is misleading and not always true [2,4,24]. According to Armend'ariz and Labie [27], there are two explanations supporting the argument that average loan size may not be a correct indictor of mission drift. One is progressive lending, which is the process of increasing the loan size of existing borrowers based on their credit history. The second one is cross-subsidization, where MFIs start serving unbanked wealthier clients with the objective of generating enough finance that enable them to reach out more poor people. Moreover, due to the fact that, average loan size of developed and developing countries is different, regional specific parameters are also considered as a context of interpreting risk of mission drift [27]. Their argument is also supported by Mersland and Storm [2] state that providing larger loan is not related with mission drift rather institutional variables.

Moreover, the shift of MFIs in their portfolio from reaching more women to men [32], from group lending to individual, and from rural to urban are considered as mission drift [33]. Thus, it can be thought out that the framework to guide mission drift is ambiguous.

Based on their initial motives (profit driven and/or socially oriented), MFIs may drift from their mission, either to generate financial resources or to attract socially responsible investors [26,34]. Therefore, once more, to answer the main question proposed before, this paper interprets mission drift not merely by looking average loan size but also looking whether the shifting trend of creeping from serving poor segment of customers to the better-off clients motivates by financial objective (nether cross-subsidization nor progressive lending).

\section{Competition and Mission drift: Theoretical Model}

In the banking literatures, regarding to competition there are two opposing theories, competition-stability or concentration-Fragility and competition-fragility or Concentration-Stability. Competitionstability theory states that competitive banking market allows banks to mitigate risks and ensure financial stability [35]. On the other strand, Concentration-Stability asserts that high competition impend banks' financial performance and leads to financial market failures [36].

Figure 1 shows the theoretical model of competition and mission

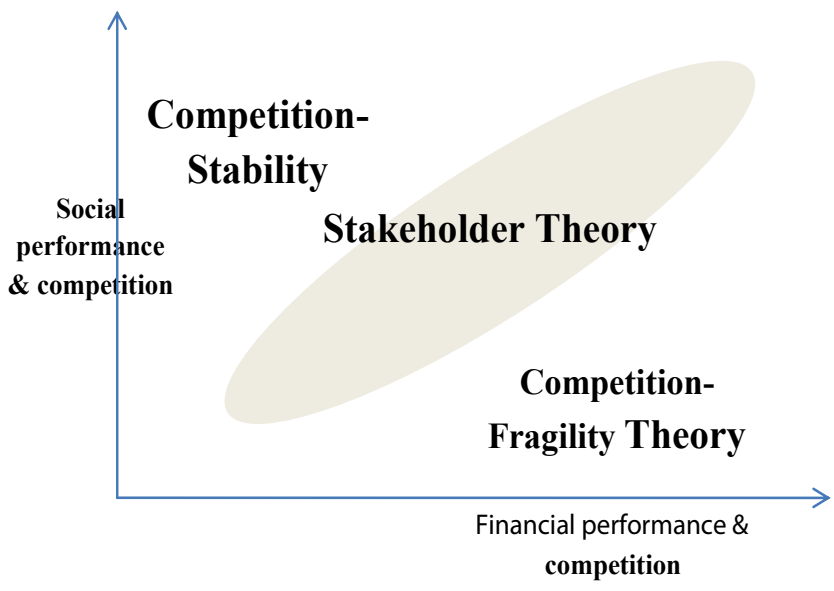

Figure 1: Theoretical model on competition and mission drift. drift. In less competitive market (competition-fragility theory), financial institution charges high interest rate that in turn increases borrowers' risk taking behavior [37]. According to these authors, in a concentration market banks have monopoly rent seeking behavior. Thus, borrowers' high risk exposure leads to moral hazard problems. In consistent with this, Rosenberg et al., Helms and Reille [12,13] find that less competition spurring MFIs to charging high interest rate on their loan amount and motivates by the intention to generate high profit [8]. Although, country specificity matters for high interest rates [7], if the increases in loan price motivates by the need for profit rather than the need to cover costs, one can claim mission drift [2]. Therefore, it appears that competition-fragility or concentration-stability theory is in favour of mission drift.

Additionally, less competitive market (competition-Fragility theory) enables MFIs to charge high interest rate, which enhance their financial performance [38]. But charging high interest rate reduces outreach [16,39]. In Figure 1, the $\mathrm{x}$-axis represents that the increase in financial performance reduces social performance. So, based on this theory, in such market structure, there exists a probability of mission drift.

In the other way round, competitive market helps borrows to having financial accesses at reasonable price. As indicated in the graph, this illustrates by the increase in social performance reduces financial performance. When competition concerns from microfinance point of views, competition theories suggest an indirect relationship between social mission and financial performance. Therefore, searching for theory that embedded social capital on it is important. One of this is stakeholder theory that helps to understand how could be MFIs operating in such instances to compromising financial and social interest of MFIs.

Stockholder theory states that firms can jointly optimize social and financial performance whereby their participation in social development activities and incorporating stakeholders in their decision making process have direct contribution for financial sustainability [40]. Hence, this theory could be serving as framework to handle a mission drift problem.

\section{Competition and Mission drift: Empirical Evidences}

Since, researchers have exposed both negative and positive impact of competition on MFIs' social mission. In this section, both competitions' effects are reviewed. First, microfinance empirical evidences that support competition hasn't a mission drift impact hypothesis are examined. Then, analyses on hypothesis that competition has a mission drift effect follows.

\section{Competition-hasn't-Mission drift hypotheses}

Cull et al. examine the effect of competition from mainstream bank on MFIs' performance (profitability and outreach) [41]. The results of their study suggest that competition has both negative and positive effect on MFIs performance. According to them, when competition from commercial bank become strong, MFIs starts to serve the unmeet market demand of poor people - maximize depth of outreach. Furthermore, they assert that, although, competition helps to maximize depth of outreach by pushing MFIs towards the marginalized segment, these MFIs also experience low financial performance (low profitability). In line with Cull et al., [41] from transaction cost perspective, Paxton et al. [20] state that social performance and financial performance have trade-off relationship. 
In related paper, Vanroose and D'Espallier investigate the relationship between competition from commercial bank and MFIs' performance (outreach and financial). The results of their analysis have twofold. On the one hand, MFIs operating in countries where there is less devolved formal banking system, which means low competition, are also serving the unbanked wealthier people. This is because, in less developed financial market, commercial banks are unable to fulfill the market demand alone. Reaching the better-off unbanked population brings high loan size in MFIs' portfolio. Thus, in such market scenario, MFIs have a room to go up in the market to serve the unbanked betteroff people as well, which increases breadth of outreach; that is "in line with their mission and with the market-failure" theory. On the other hand, in countries where there is well developed financial sector, since MFIs faced strong competition from commercial banks, MFIs push towards the marginalized segment. This findings support Cull et al.'s argument in such a way that, in both cases, increased competition from formal banking sector directs MFIs to focus on the vulnerable poor people [41]. Hence, MFIs are obliged to offer smaller loan sizes, depth of outreach.

Moreover, in their paper about "a model in mission drift MFIs", Ghosh and Van Tassel find that due to induced by profit hunger donors [26], successful MFIs are shifting from poor clients segment to the better-off clients. Nevertheless, they don't confirm occurrence of mission drift phenomena in microfinance. They argue that "...drift from smaller loans to larger loans is in perfect consonance with the objective of poverty minimization". But it ...... "does signify a decreasing poverty return for the most effective microfinance institutions" [26]. However, they don't regret to confirm the difficulty of interpreting mission drift phenomena, and its vague and exigent debates.

\section{Competition-mission drift hypotheses}

McIntosh and Wydick argue the entry of new MFI into market to compete for profit within the same pool of clients threatens the resource generating capacity of MFIs [22]. They assert that socially defined MFIs face shortage of financial resources that used to cross-subsidized their poor borrowers. Additionally, they claim that as competition increased within the same target borrowers, socially motivated MFIs start to follow market penetration strategy (e.g., reducing loan price) against their counter parts to attract and incorporate the better-off borrowers in their portfolio.

The paper of Navajas et al. examines Bolivian microfinance market [21]. Among various issues investigated in this paper, impact of competition on microfinance is one. They find that lending methodology is the determinant of profit. According to them, if the right lending methodology is designed and implemented, microfinance business is profitable. Additionally, they argue that competition encouraging MFIs to diversify their products and services in line with the needs of each segment of the population. Such customization enhances the poor's chance of getting products and services that best suits their needs. Since, competition reduces the monopoly power of sole-provider in microfinance market; it increases access to financial services. But they posit these positive contributions of competition by arguing that competition decreases outreach of efficient MFIs and influences their effort to make cross-subsidize for poor borrowers. It means competition decreases outreach performances of Pioneer MFIs which abele to reach more clients in the early stage of microfinance development. Thus, according to Navajas et al. for successful MFIs, competition pushes them to instil into the less poor clients by crowding out the needy [21].
Summarizing the above empirical evidences suggest that the results are ambiguous and mixed on whether competition has a mission drift impact. For instance, there are evidences present that microfinance is starting crowding out poor people [21-23]. On the other hand, there are also empirical evidences suggesting that although, MFIs are striving to be financially sustainable, MFIs are still operating for their original mission, so, mission drift is not confirmed $[2,41,42]$.

\section{Conclusions}

This paper analyzed both theoretical and empirical evidences on the effect of competition on MFIs' social mission to pin-down whether competition has a mission drift impact. Although the review of the paper suggests that the results are mixed and ambiguous, the following conclusion is drawn. The influence of competition on MFIs' mission is twofold.

On one hand competition hasn't a mission drift impact. Competition helps MFIs to keep their mission of serving the marginalized poor people in such a way that competition pushes MFIs towards the unmet market demand. To put differently, competition has a positive association with depth of outreach. It implies that when competition increased, MFIs' depth of outreach also increased. In such scenarios, competition doesn't leads to mission drift.

Similarly, in less developed formal financial sector where MFIs are serving all kinds of unbanked population demonstrate broad breadth of outreach. In such kind of market, as long as MFIs don't crowding out poor clients, offering larger loan size to reach out unbanked wealthier people is not a mission drift. In this case, competition (Although it is less) spurring MFIs to extend their market and incorporate the better-off clients in their portfolio which allow them to make crosssubsidization. Moreover, for those efficient MFIs motivates by donors' fund, the shift in their portfolio towards the less poor segments of population indicates the shallow effect of donors' fund on fighting poverty, yet in line with MFIs' mission.

In support of the above conclusion, the theoretical evidences suggest that collusion (less competition) leads to mission drift. So, theoretically, competition seems important to control mission drift phenomena.

On the other hand, however, competition has also a mission drift effect. Competition influences the financial capacity of socially motivated MFIs. In a competitive market there exists a situation where MFIs become unable to get their money back (low repayment rate due to high loan burden), which in turn hamper their efficiency, and then start to look for portfolio or transaction that costs less and profitable. Therefore, competition threatens their cross-subsidization ability and that leads to crowding out poor borrowers, where a mission drift occurs.

Altogether, the effect of competition on mission drift is ambiguous and an ongoing debate. It is difficult to disentangle whether the phenomena of mission drift has occurred due to competition or other factors. On top of that, the effect of competition on MFIs' mission subjects to market or country or institutional specific variables. Thus, further study is needed to find out a framework that could be disciplines MFIs' mission to operate in a comparative environment without creping from their defined social mission.

\section{References}

1. Labie M (1999) Microfinance in questions: Limits and organizational choices. 
Citation: Wondirad HA (2018) Competition and Mission Drift in Microfinance: Does Competition has a Mission Drift Impact? J Bus Fin Aff 7: 324 . doi: $10.4172 / 2167-0234.1000324$

Page 5 of 5

2. Mersland R, Strøm Rø (2010) Microfinance mission drift? World Development 38: 28-36.

3. Morduch J (2000) The microfinance schism. World Development 28: 617-629.

4. Cull R, Demirgüç-Kunt A, Morduch J (2011) Does regulatory supervision curtail microfinance profitability and outreach? World Development 39: 949-965.

5. Maes JP, Reed LR (2012) State of the microcredit summit campaign report 2012. Microcredit Summit Campaign.

6. Littlefield E, Kneiding C (2009) The global financial crisis and its impact on microfinance. Focus Note, World Bank.

7. Armendáriz B, Szafarz A (2009) Microfinance mission drift? Université Libre de Bruxelles, Solvay Brussels School of Economics and Management, Centre Emile Bernheim (CEB)

8. Bateman M (2010) Why doesn't microfinance work? the destructive rise of local neoliberalism London.

9. Assefa E, Hermes N, Meesters A (2013) Competition and the performance of microfinance institutions. Applied Financial Economics 23: 767-782.

10. Christen RP (2001) Commercialization and mission drift: Evidence from a Large Chinese Microfinance Institution.

11. World Bank (2008) Finance for All? Policies and Pitfalls in Expanding Access Washington, DC.

12. Rosenberg R, Gonzalez A, Narain S (2009) Are microcredit interest rates excessive? CGAP Brief.

13. Helms B, Reille X (2004) Interest rate ceilings and microfinance: The story so far. Consultative group to assist the poorest (CGAP).

14. Mersland R, Strøm Rø (2009) Performance and governance in microfinance institutions. Journal of Banking \& Finance 33: 662-669.

15. Woller GM, Dunford C, Woodworth W (1999) Where to microfinance. International Journal of Economic Development 1: 29-64.

16. Woller G (2002) The promise and peril of microfinance commercialization Small Enterprise Development 13: 12-21.

17. Rhyne E (1998) The yin and yang of microfinance: Reaching the poor and sustainability. Micro Banking Bulletin 2: 6-8.

18. Drake D, Christen RP (2002) Commercialization of Microfinance: Balancing Business and Development. The new reality of microfinance, pp: 2-21.

19. Hishigsuren G (2007) Evaluating mission drift in microfinance: Lessons for programs with social mission. Evaluation Review 31: 203-260.

20. Paxton J, Graham D, Thraen C (2000) Modeling group loan repayment behavior: New insights from burkina faso. Economic Development and Cultural Change 48: 639-655.

21. Navajas S, Conning J, Gonzalez-Vega C (2003) Lending technologies, competition and consolidation in the market for microfinance in bolivia. Journal of International Development 15: 747-770.

22. McIntosh C, Wydick B (2005) Competition and microfinance. Journal of Development Economics 78: 271-298.
23. Harper M, Dichter TW (2007) What's wrong with microfinance? Rawat Booksellers.

24. Schreiner M (2002) Aspects of outreach: A framework for discussion of the social benefits of microfinance. Journal of International Development 14: 591-603.

25. Cull R, Morduch J (2007) Financial performance and outreach: A global analysis of leading microbanks. The Economic Journal 117: F107-F133.

26. Ghosh S, Van Tassel E (2008) A model of mission drift in microfinance institutions. Florida Atlantic University, USA.

27. Armendáriz B, Labie M (2011) The handbook of microfinance. World scientific New Jersey.

28. Motta M (2004) Competition policy: Theory and practice. Cambridge University Press.

29. Rhyne E, Otero M (2006) Microfinance through the next decade: Visioning the who, what, where, when and how ACCION International, pp: 1-66.

30. Vogelgesang $U$ (2003) Microfinance in times of crisis: The effects of competition, rising indebtedness, and economic crisis on repayment behavior. World Development 31: 2085-2114.

31. Bhatt N, Tang S (2001) Delivering microfinance in developing countries: Controversies and policy perspectives. Policy Studies Journal 29: 319-333.

32. Dowla A, Barua D (2006) The poor always pay back: The grameen II story Kumarian Press.

33. Thorp R, Stewart F, Heyer A (2005) When and how far is group formation a route out of chronic poverty? World Development 33: 907-920.

34. Cull R, Demirgüç-Kunt A, Morduch J (2008) Microfinance meets the market World Bank Policy Research Working Paper Series 92: 1-30.

35. Beck T (2008) Bank competition and financial stability: Friends or foes? World Bank Policy Research Working Paper Series, pp: 1-32.

36. Carletti E, Hartmann P (2002) Competition and stability: What's special about banking? European Central Bank pp: 1-49.

37. De Nicolo G, Boyd JH (2005) The theory of bank risk taking and competition revisited. The Journal of Finance 60: 1329-1343.

38. Sun SL, Im J (2015) Cutting microfinance interest rates: An opportunity CoCreation perspective. Entrepreneurship Theory and Practice 39: 101-128.

39. Hermes N, Lensink R, Meesters A (2008) Outreach and efficiency of microfinance institutions. World Development 39: 938-948.

40. Harrison JS, Freeman RE (1999) Stakeholders, social responsibility, and performance: Empirical evidence and theoretical perspectives. Academy of management Journal 42: 479-485.

41. Cull R, Demirgüç-Kunt A, Morduch J (2009) Microfinance meets the market. Journal of Economic Perspectives 23: 167-192.

42. Cull R, Demirguc-Kunt A, Morduch J (2006) Financial performance and outreach: A global analysis of leading microbanks. Research Working Papers 1: $1-51$ 